\title{
Distribution and Potential Availability of As, Metals and P in Sediments from a Riverine Reservoir in a Rural Mountainous Catchment (NE Portugal)
}

\author{
Anabela R. Reis ${ }^{1,2}$, Marta Roboredo ${ }^{3}$, João P. R. M. Pinto ${ }^{4}$, Bernardete Vieira ${ }^{5}$, Simone G. P. Varandas ${ }^{6} \mathbb{D}$, \\ Luis F. S. Fernandes ${ }^{7}$ (D) and Fernando A. L. Pacheco ${ }^{8, *(1)}$
}

check for updates

Citation: Reis, A.R.; Roboredo, M.; Pinto, J.P.R.M.; Vieira, B.; Varandas, S.G.P.; Fernandes, L.F.S.; Pacheco, F.A.L. Distribution and Potential Availability of As, Metals and P in Sediments from a Riverine Reservoir in a Rural Mountainous Catchment (NE Portugal). Int. J. Environ. Res. Public Health 2021, 18, 5616. https:// doi.org/10.3390/ijerph18115616

Academic Editor: Paul B. Tchounwou

Received: 3 May 2021

Accepted: 21 May 2021

Published: 24 May 2021

Publisher's Note: MDPI stays neutral with regard to jurisdictional claims in published maps and institutional affiliations.

Copyright: (c) 2021 by the authors Licensee MDPI, Basel, Switzerland. This article is an open access article distributed under the terms and conditions of the Creative Commons Attribution (CC BY) license (https:/ / creativecommons.org/licenses/by/ $4.0 /)$.
1 Department of Geology, School of Life and Environmental Sciences, University of Trás-os-Montes e Alto Douro (UTAD), 5000-801 Vila Real, Portugal; anarreis@utad.pt

2 Geosciences Centre, University of Coimbra (Polo II), 3030-790 Coimbra, Portugal

3 Chemistry Center Vila Real, Department of Biology and Environment, School of Life and Environmental Sciences, University of Trás-os-Montes e Alto Douro (UTAD), 5000-801 Vila Real, Portugal; roboredo@utad.pt

4 Amber Energy, Cardiff CF10 1FS, UK; jmoutinho7@gmail.com

5 School of Agrarian and Veterinary Sciences, University of Trás-os-Montes e Alto Douro (UTAD), 5000-801 Vila Real, Portugal; bvieira@utad.pt

6 Centre for Research and Technology of Agro-Environment and Biological Sciences, Department of Forestry and CITAB/UTAD, University of Trás-os-Montes and Alto Douro (UTAD), 5000-801 Vila Real, Portugal; simonev@utad.pt

7 Centre for Research and Technology of Agro-Environment and Biological Sciences, Department of Engineering and CITAB/UTAD, University of Trás-os-Montes and Alto Douro (UTAD), 5000-801 Vila Real, Portugal; lfilipe@utad.pt

8 Chemistry Center Vila Real, Department of Geology, University of Trás-os-Montes e Alto Douro (UTAD), 5000-801 Vila Real, Portugal

* Correspondence: fpacheco@utad.pt

Abstract: A geochemical investigation was carried out on the bottom sediments of a riverine reservoir, located in a mountainous rural region (NE Portugal), with the aim of evaluating the contents of As, metals and $\mathrm{P}$ and their potential availability. The elements contents were detected in the following ranges ( $\left.\mathrm{g} \mathrm{g} \mathrm{g}^{-1}\right)$ : As (18-64); Cr (32-128); Cu (39-93); Ni (18-80); Pb (49-160); Zn (207-334); $\mathrm{P}$ (1705-2681). The reducible fraction is the most significant in the retention of the elements. Based on their potential relative mobility, the detected metals could be classed as follows: $\mathrm{Zn}>\mathrm{As}, \mathrm{Pb}>\mathrm{Cu}$ $>\mathrm{Cr}$, Ni. The results on geochemical partitioning were revealed to be important when the Sediment Quality Guidelines (SQGs) were considered. Arsenic, $\mathrm{Cr}$, Ni, Pb and $\mathrm{Zn}$ showed total contents exceeding the values of Probable Effect Level (PEL), but only As occurred in the most potentially available form; $\mathrm{Cr}$ and $\mathrm{Ni}$ can be considered relatively unavailable, since these are mainly associated with the residual phase. Locally, oxygen depletion could release $\mathrm{P}$ into the water column due to the higher concentrations in Fe-P and CDB-P fractions. The potential availability of As, metals and $P$ in sediments indicates that the quality of sediments accumulated in small reservoirs should be considered in management policies.

Keywords: sediments; riverine reservoir; metals; phosphorus; chemical fractionation; potential availability

\section{Introduction}

The significant role of fine sediments in the transport and fate of contaminants in aquatic environments is well documented-e.g., [1-9]. Metals, which can be derived from point sources, such as industry, mining and smelting, and urban effluents, as well as from diffuse pollution sources, such as urban activities and agriculture, may exert direct toxic effects on aquatic biota and also accumulate in organisms consumed by humans. Analysis of metals in sediments can be used to assess anomalies in their concentration, which can be attributed to a geogenic origin or to pollution created by human activities. 
Metals in sediments are present in different chemical forms (easily exchangeable ions, metal carbonates, oxides, sulfides, organometallic compounds, ions in crystal lattices of minerals, etc.), which determine their mobilization capacity and potential bioavailabilitye.g., $[1,2,10]$. The assessment of metal partitioning in sediment gives information on their release through anthropogenic activities, as supposedly, metals are mainly associated with reactive particulate phases, which are highly sensitive to physical-chemical changes within the river environment [2,8]; differently, the lithological contribution to metals in sediments is mainly associated with the crystal lattices of minerals, with limited mobility.

Phosphorus concentration in European rivers, and the related eutrophication issues, have been a major environmental concern in recent decades [11,12]. The Water Framework Directive $[11,13,14]$ recognizes this problem regarding the impact on surface water quality. Thanks to legislation and to the efforts of some governments, recent studies have reported a decline in $\mathrm{P}$ content in European rivers in recent years [15-17]. In dam reservoirs, phosphate ion $\left(\mathrm{PO}_{4}{ }^{3-}\right)$ is easily sorbed into sediments. Finer particles $(<2 \mu \mathrm{m})$, consisting of clays, carbonates, Fe and $\mathrm{Al}$ oxides and humic acids, are more effective in adsorbing $\mathrm{P}$ due to their higher surface area. The mechanism of phosphate adsorption is generally dominated by ligand exchange in which two individual coordinated hydroxyl groups or water molecules are replaced by a single phosphate anion, resulting in the formation of a bidentate, binuclear complex [18-23]. The phosphate surface complexes are very stable and result in slow exchange rates and an apparent irreversibility of $\mathrm{P}$ adsorption, leading to long-term P storage in soils, sediments and wetlands $[19,20,22]$. However, at the interface of the water body/sediments, oxygen depletion due to organic matter decomposition (phytoplankton, limnic vegetation or organic wastes) helps to dissolve the Fe-P complex to form soluble Fe (II), releasing P [24-26]. Reductive dissolution of poorly crystalline Fe oxides is the main process explaining the remobilization of $\mathrm{P}$ in sediments: adsorbed or occluded $\mathrm{P}$ is released and can be fixed as another $\mathrm{P}$ form (adsorbed on crystalline $\mathrm{Fe}$ oxides or precipitated).

The transport of sediments by rivers to the oceans on a global scale is significantly altered by the construction of dams [27-29], which decrease sediment transport by trapping them in reservoirs. The reservoirs generated upstream of dams constructed for hydropower purposes can be divided into two major types: artificial lake reservoirs and riverine reservoirs $[27,30]$. In the "artificial lake reservoir", the water storage and release cycles take place over a long period of time and operate on at least seasonal cycles; the major impacts associated with this type of reservoir are the removal of suspended sediments and nutrients and changes in discharge and thermal regimes downstream of the dams. The "riverine reservoir" resembles a river with good mixing and relative high water velocities, with the major impacts being the disruption of the river flow and sediment transport and the change in river morphology downstream of the dams.

Small reservoirs have a lower sediment retention capacity but are widely distributed in regulated basins. Therefore, small reservoirs collectively impart an important anthropogenic signature to the global sediment flux, increasing mean sediment retention by $23 \%$ when compared to estimates of mean sediment retention for large reservoirs (30\%) [27]. In mountain rivers, short and intense precipitation episodes involve the transport of significant sedimentary loads, with associated pollutants, in a spasmodic regime.

Sediment entrapment in reservoirs may also mean the trapping of metals and $\mathrm{P}$, depending on the occurrence of contamination sources in the upstream drained areas. Metals associated with sediments may return to the sediment-water interface through diffusion, sediment re-suspension, or biological activity such as bioturbation-e.g., [31-34]; the quality of the water column can then deteriorate. Several studies have been carried out on reservoirs and the related quality of the sedimentary compartment [33-38], but changes in sediment-associated contaminants after prolonged exploitation of dams are still not fully understood due to the diversity of the influencing factors.

Small-sized reservoirs have received little to no attention, in particular "riverine reservoirs", located in mountainous regions. In these regions, pollution signals referring to 
potentially harmful elements, which can be associated with the sedimentary component of these aquatic systems and influence their environmental quality, are not directly observed.

In this context, a small riverine reservoir, draining an area with rural and urban land use, located in a mountainous region with a temperate climate, was selected to develop a study on the environmental quality of bottom sediments. Previous studies $[39,40]$ performed on oxic fluvial sediments, in the area drained by the tributaries upstream of the reservoir, showed considerable contents of metals associated with finer particles $(<63 \mu \mathrm{m})$.

The aim of this study was (a) to collect data on the contents of As, selected metals and $\mathrm{P}$ in the reservoir bottom sediments and identify their spatial distribution pattern; and (b) to investigate the different geochemical forms present and to obtain information on the mechanisms of retention of metals in the reservoir sediments using a four-step sequential extraction procedure. The results were analyzed in terms of pollution based on EF (enrichment factor) and ecological risk, based on RAC (risk assessment code) and the sediment quality guidelines-SQGs. This analysis allowed us to characterize the level of contamination of sediments in relation to toxic elements and to infer the potential mobilization of metals from the sediments to the water column. The quality of the water column in the reservoir was also assessed through the measurement of the main physicalchemical parameters in bottom and surface water samples.

\section{Materials and Methods}

\subsection{Study Area}

The studied dam reservoir is located near the urban area of the town of Vila Real, in the Trás-os-Montes e Alto Douro province, Northwest Portugal. The reservoir is located along the River Corgo, at an altitude of $307 \mathrm{~m}$, just downstream of the confluence with its largest tributary, the River Cabril. The drainage network of the River Corgo develops in a rural mountainous catchment. The river is a tributary in the trans-boundary River Douro basin, in the well-known Douro Region-a world heritage site classified by UNESCO.

The Terragido dam (latitude: $41^{\circ} 17^{\prime} \mathrm{N}$; longitude: $7^{\circ} 44^{\prime} \mathrm{W}$ ) is a mini-hydropower dam, operational in its present form since 1926. Originally, it was a weir belonging to the first hydroelectric exploitation unit constructed in Portugal, in 1894. The reservoir has a medium inundated area of $25 \times 10^{3} \mathrm{~m}^{2}$; the volume of water is estimated at $45.5 \times 10^{3} \mathrm{~m}^{3}$; the mean discharge is $6.4 \mathrm{~m}^{3} \mathrm{~s}^{-1}$.

For several decades, urban effluents from the urban area of Vila Real and other urban sites distributed in the drained area were discharged into the river network. The water in the Terragido reservoir was of poor quality, turbid and malodorous, with visible accumulation of garbage. The wastewater treatment plant of Vila Real was constructed in the margins of the River Cabril, in 2004, near the dam, and the effluents currently discharge into the main river downstream.

Upstream of the dam, the geology of the drained area is composed essentially of granites with dispersed outcrops of shists; quartz veins are dispersed in the area [41,42]. Locally, the crystalline rocks are covered by quaternary deposits. The altitudes in the basin vary between 300 and $1400 \mathrm{~m}$. Vila Real is located at an altitude of $450 \mathrm{~m}$. The mean annual precipitation is $974 \mathrm{~mm}$, varying between 672 and $1900 \mathrm{~mm}$.

The land use is mainly represented by forestry and natural vegetation in the highlands, while agriculture predominates in the valleys. Urban settlements are spread throughout the drained area. Industrial activity is scarce. The main polluting activities are represented by agriculture (pollution by sediments/soil particles, metals and fertilizers), urban activities (such as vehicular traffic, diverse residential activities, soil erosion) and a few industrial activities such as horticulture, silviculture and cattle raising.

\subsection{Sampling and Sample Preparation}

Taking into account the size of the reservoir, to perform this study, a total of 9 samples of bottom sediments and 16 samples of water were collected at the end of the dry season, in October (Figure 1). In the reservoir, 7 sampling sites were selected to collect sediments 
and water samples at 2 depths: surface and near the bottom. In the tributaries, near the confluence with the reservoir, 2 samples of bottom sediments and water were collected. The sediments were collected using a Van Veen grab sampler. The grab was dropped carefully to collect the finer and most recently deposited sediments (the top layer of about $5 \mathrm{~cm}$ ). About 1 to $3 \mathrm{~kg}$ of a representative sample was collected. The bottom water samples were collected with a Van Dorn bottle, with a capacity of $3 \mathrm{~L}$. The samples were stored in plastic bags and bottles, adequately sealed and identified, transported to the laboratory at low temperature in thermos boxes and stored at $4{ }^{\circ} \mathrm{C}$ prior to analysis. At each sampling site, temperature, $\mathrm{pH}$, electrical conductivity (EC) and dissolved oxygen were measured.

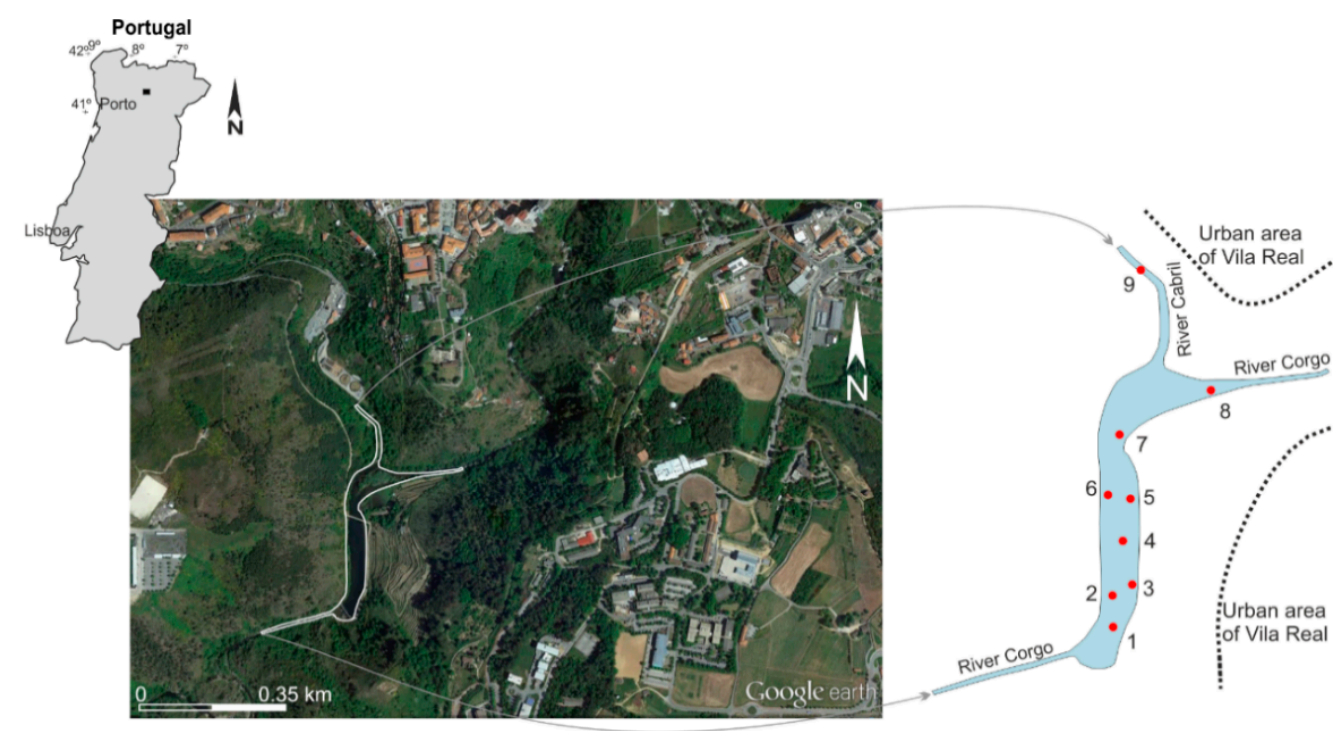

Figure 1. Image of the Terragido dam reservoir, in the River Corgo catchment, Northwest Portugal (latitude: $41^{\circ} 17^{\prime} \mathrm{N}$; longitude: $7^{\circ} 44^{\prime} \mathrm{W}$ ), and sampling sites $(\bullet)$.

Sediments were wet-sieved with ultra-pure water to separate the $<63 \mu \mathrm{m}$ fraction, to minimize the effects of variable grain size. In sediment studies, the analysis of the fraction $<63 \mu \mathrm{m}$ is recommended [43] because clay and silt particles generally contain the highest concentrations of pollutants and are most readily transported in suspension in natural waters.

\subsection{Water Analyses}

In the laboratory, the measurement of alkalinity, expressed as $\mathrm{mg} \mathrm{L}^{-1}$ of $\mathrm{HCO}_{3}{ }^{-}$, was made through acidimetric titration based on the Gran procedure $[44,45]$. The titrant acid used was $0.102 \mathrm{~N} \mathrm{HCl}$, in a $\mathrm{pH}$ range of 4.5 to 3.0, in $100 \mathrm{~mL}$ aliquots of reservoir water samples. The cations were determined via Flame Atomic Absorption Spectroscopy (Thermo Fisher Scientific iCE 3000, Thermo Fisher Scientific, Waltham, MA, USA). The anions were determined via Ion Chromatography (Thermo Fisher Scientific Dionex ICS3000, Thermo Fisher Scientific, Waltham, MA, USA). Standards and blanks were run with each batch of samples. Accuracy was within 5\% of the certified values, and the analytical error (relative standard deviation) was better than $5 \%$.

\subsection{Sediment Analyses}

In order to investigate the mechanisms of retention, and the potential mobilization of As and metals $(\mathrm{Cd}, \mathrm{Cr}, \mathrm{Ni}, \mathrm{Co}, \mathrm{Cu}, \mathrm{Pb}, \mathrm{Zn}, \mathrm{Fe}, \mathrm{Mn}$ ) in the sediments, the modified BCR (Community Bureau of Reference of the European Commission) sequential-extraction procedure [46] was used. This method separates three chemical phases: (a) available- exchangeable metals and metals bound to carbonates $\left(0.11 \mathrm{M} \mathrm{CH}_{3} \mathrm{COOH}\right)$; (b) reducible-metals bound to Fe and Mn oxides ( $\left.0.5 \mathrm{M} \mathrm{NH}_{2} \mathrm{OH} . \mathrm{HCl}\right)$; and (c) oxidizable-metals bound to organic matter and sulfides $\left(8.8 \mathrm{M} \mathrm{H}_{2} \mathrm{O}_{2} ; 1 \mathrm{M} \mathrm{NH}_{4} \mathrm{COOCH}_{3}\right)$. The residual fraction was then digested with aqua 
regia. The elemental concentrations were obtained by ICP-OES (Perkin Elmer Optima 7300DV, Perkin Elmer Inc., Waltham, MA, USA).

The Chang and Jackson [47] inorganic P fractionation was carried out in sediments according to the Kuo [48] proposal. The fractionation of inorganic $P$ allows the identification of the different chemical fractions present in sediments that influence the dynamics of this element in the sediment-water systems [48,49]. Six fractions with different degrees of solubility are separated: (i) $\mathrm{NH}_{4} \mathrm{Cl}-\mathrm{P}$, soluble and loosely bound $\mathrm{P}\left(1 \mathrm{M} \mathrm{NH} \mathrm{Nl}_{4} \mathrm{Cl}\right)$; (ii) $\mathrm{Al}-\mathrm{P}$, $\mathrm{P}$ linked to aluminum oxides and hydroxides $\left(0.5 \mathrm{M} \mathrm{NH}_{4} \mathrm{~F}\right.$; $\left.\mathrm{pH} 8.2\right)$; (iii) Fe-P, $\mathrm{P}$ linked to iron oxides and hydroxides $(0.1 \mathrm{M} \mathrm{NaOH})$; (iv) CBD-P, reductant soluble (occluded) iron phosphate $\left(0.3 \mathrm{M} \mathrm{Na}_{3} \mathrm{C}_{6} \mathrm{H}_{5} \mathrm{O}_{7} ; 1 \mathrm{M} \mathrm{NaHCO} 3\right.$ and $\mathrm{Na}_{2} \mathrm{~S}_{2} \mathrm{O}_{4}$ ); (v) Ca-P, Ca bound $\mathrm{P}$ $\left(0.25 \mathrm{M} \mathrm{H}_{2} \mathrm{SO}_{4}\right)$; and (vi) residual $\mathrm{P}$ evaluated through a $\mathrm{HClO}_{4}$ digestion. Phosphorus in the extracts was analyzed through molecular absorption spectrophotometry at $880 \mathrm{~nm}$ using a segmented flow auto analyzer (Skalar Analytical B.V., Breda, The Netherlands).

In each analytical sequence, 3 replicates were used to assess repeatability (results are presented as a mean value). To ensure accuracy, an in-house laboratory reference material was also used in each batch. The original samples were also digested with aqua regia to determine the total amounts of As and metals present in the samples, allowing comparison with the sum of the amounts relative to each sequential-extraction step. The recovery rates (the sum of 4 fractions/total concentration) ranged from $91 \%$ to $109 \%$. The precision of the measurements was about $\pm 5 \%$.

\subsection{Risk Assessment of Sediment Contamination}

The potential environmental risk associated with the As and metals was assessed from the total and from the fractionation contents. To estimate the anthropogenic contribution of the elements in sediments, the enrichment factor (EF) after [50] was calculated, whose classification is based on the ratio between the measured metal concentration and the metal geochemical background, using a normalizer element. Data on shallow water sediment (Wedepohl, in [2]) were used as background values and $\mathrm{Fe}$ as a normalizer element [51]. The ecological risk associated with each element was assessed via the risk assessment code (RAC), after Perin et al. [52], which is based on the percentages of exchangeable and carbonate-bound metals in sediments. The toxicity of the sediments was also assessed by the consensus-based sediment quality guidelines (SQG), introduced by Macdonald et al. [53], the threshold effect concentration (TEL) and probable effect level (PEL). A concentration of an element below the TEL means that undesirable effects are not expected, while above the PEL, adverse effects are expected to occur.

\section{Results and Discussion}

\subsection{Waters}

In Table 1, selected physical and chemical characteristics of the reservoir water are shown. In the water samples, the metals considered in this study were below the detection limits. The results on the water physical parameters, chemical elements and compounds did not allow inferring spatial variability through the water column or along the water reservoir (Table 1). The waters showed low mineralization, with conductivity values varying in the range of $55.7-62.1 \mu \mathrm{S} \mathrm{cm} \mathrm{cm}^{-1}$. An extreme value of $130.6 \mu \mathrm{S} \mathrm{cm}^{-1}$ was registered at sampling site 1 , at the bottom of the reservoir, near the dam wall. The reservoir water was slightly acid, with $\mathrm{pH}$ values varying between 6.2 and 6.8. The registered values of dissolved $\mathrm{O}_{2}$ showed little variation, in the range of 10.48 to $12.52 \mathrm{mg} \mathrm{L}^{-1}$. The lowest value was observed near the dam, while in the River Corgo, it was higher $\left(12 \mathrm{mg} \mathrm{L}^{-1}\right)$. In general, no significant differences were observed between bottom and surface water measurements. 
Table 1. Values of physical and chemical parameters of the surface and of the bottom of the water column in the Terragido reservoir (B-bottom water; S-surface water).

\begin{tabular}{|c|c|c|c|c|c|c|c|c|c|c|}
\hline \multirow{2}{*}{ Parameters } & \multicolumn{2}{|c|}{ Maximum } & \multicolumn{2}{|c|}{ Minimum } & \multicolumn{2}{|c|}{ Average } & \multicolumn{2}{|c|}{ Median } & \multicolumn{2}{|c|}{$\begin{array}{l}\text { Standard } \\
\text { Deviation }\end{array}$} \\
\hline & B & $S$ & B & $S$ & B & S & B & $S$ & B & $S$ \\
\hline Temperature $\left({ }^{\circ} \mathrm{C}\right)$ & 8.30 & 8.70 & 7.50 & 4.70 & 7.90 & 7.29 & 7.90 & 7.80 & 0.29 & 1.33 \\
\hline Conductivity $\left(\mu \mathrm{Sm}^{-1}\right)$ & 130.60 & 68.60 & 55.80 & 55.70 & 67.61 & 58.94 & 56.20 & 56.00 & 27.85 & 4.88 \\
\hline Dissolved oxygen $\left(\mathrm{mg} \mathrm{L}^{-1}\right)$ & 11.10 & 12.52 & 10.50 & 10.80 & 10.94 & 11.35 & 11.00 & 11.01 & 0.20 & 0.68 \\
\hline $\mathrm{pH}$ & 6.46 & 6.57 & 6.31 & 5.40 & 6.42 & 6.19 & 6.44 & 6.41 & 0.05 & 0.43 \\
\hline $\mathrm{NO}_{3}\left(\mathrm{mg} \mathrm{L}^{-1}\right)$ & 8.50 & 9.50 & 1.63 & 1.62 & 4.22 & 4.32 & 3.25 & 4.60 & 2.56 & 2.59 \\
\hline $\mathrm{NO}_{2}\left(\mathrm{mg} \mathrm{L}^{-1}\right)$ & 0.19 & 0.21 & 0.18 & 0.15 & 0.18 & 0.18 & 0.18 & 0.17 & 0.01 & 0.02 \\
\hline $\mathrm{Ca}\left(\mathrm{mg} \mathrm{L}^{-1}\right)$ & 1.08 & 1.03 & 0.90 & 0.90 & 1.00 & 0.98 & 0.99 & 0.99 & 0.07 & 0.05 \\
\hline $\mathrm{K}\left(\mathrm{mg} \mathrm{L}^{-1}\right)$ & 1.14 & 1.13 & 1.05 & 1.03 & 1.09 & 1.08 & 1.08 & 1.08 & 0.03 & 0.03 \\
\hline $\mathrm{Mg}\left(\mathrm{mg} \mathrm{L}^{-1}\right)$ & 0.92 & 0.92 & 0.87 & 0.86 & 0.89 & 0.90 & 0.90 & 0.90 & 0.02 & 0.02 \\
\hline $\mathrm{Na}\left(\mathrm{mg} \mathrm{L}^{-1}\right)$ & 5.96 & 6.69 & 5.71 & 5.72 & 5.88 & 5.97 & 5.92 & 5.90 & 0.09 & 0.29 \\
\hline $\mathrm{Cl}\left(\mathrm{mg} \mathrm{L}^{-1}\right)$ & 7.10 & 7.73 & 6.31 & 6.60 & 6.71 & 6.91 & 6.78 & 6.69 & 0.29 & 0.41 \\
\hline $\mathrm{PO}_{4}\left(\mathrm{mg} \mathrm{L}^{-1}\right)$ & 6.51 & 2.61 & 1.83 & 1.82 & 2.56 & 2.00 & 1.94 & 1.94 & 1.74 & 0.24 \\
\hline $\mathrm{SO}_{4}\left(\mathrm{mg} \mathrm{L}^{-1}\right)$ & 35.00 & 38.70 & 12.50 & 9.89 & 21.63 & 20.79 & 18.70 & 18.70 & 8.24 & 10.42 \\
\hline $\mathrm{F}\left(\mathrm{mg} \mathrm{L}^{-1}\right)$ & 0.53 & 0.02 & 0.01 & 0.01 & 0.14 & 0.01 & 0.01 & 0.01 & 0.22 & 0.01 \\
\hline $\operatorname{Mn}\left(\mu \mathrm{g} \mathrm{L}^{-1}\right)$ & 11.74 & 7.39 & 0.81 & 0.67 & 3.71 & 3.16 & 2.10 & 2.80 & 3.92 & 1.92 \\
\hline Alkalinity $\left(\mathrm{mg} \mathrm{L}^{-1}\right)$ & 11.38 & 9.67 & 5.65 & 7.80 & 8.56 & 8.77 & 8.64 & 8.81 & 1.73 & 0.65 \\
\hline $\operatorname{TSS}\left(\mathrm{mg} \mathrm{L}^{-1}\right)$ & 103.00 & 91.00 & 48.00 & 43.00 & 81.14 & 66.44 & 86.00 & 66.00 & 19.14 & 14.34 \\
\hline
\end{tabular}

The results showed that, in general, the water body in the reservoir shows no significant indicators of contamination. Nevertheless, the predominance of sulfate and chloride in the anion group showed an influence of anthropogenic activities (urban and/or agriculture) in the water chemistry. The identified chemical composition reflects that of the drained lithologies and the fluvial dynamics in the mountainous catchments. We can therefore deduce that the frequent renewal of river waters has produced an effective dispersion of possible contaminating elements in aqueous solution.

\subsection{Sediments}

The comparison of the mean concentrations of As and metals in the bottom sediments from the Terragido dam obtained in this study, with the mean contents in average shale, shallow water sediment and river-suspended sediment (Table 2), indicates that the contents of the studied elements are relatively higher than the reference values for stream sediments of unpolluted rivers, in particular $\mathrm{As}, \mathrm{Cr}, \mathrm{Pb}$ and $\mathrm{Zn}$.

Table 2. Comparison of the ranges of concentrations $\left(\mu \mathrm{g} \mathrm{g}^{-1}\right)$ of metals and As in the bottom sediments from the Terragido reservoir (fraction $\leq 63 \mu \mathrm{m}$ ) with the mean contents in average shale, shallow water sediment, river-suspended sediment and PEL, LEL and PEL values.

\begin{tabular}{ccccccccccc}
\hline Reference & As & Cd & Co & Cr & Cu & Ni & Pb & Zn & P \\
\hline Average shale $^{1}$ & 13 & 90 & & 90 & 45 & 68 & 20 & 95 & 700 \\
\hline $\begin{array}{c}\text { Shallow water } \\
\text { sediment }\end{array}$ & 5 & 60 & & & 56 & 35 & 22 & 92 & 550 \\
\hline $\begin{array}{c}\text { River suspended } \\
\text { sediments }\end{array}$ & 5 & 100 & 100 & 100 & 90 & 150 & 350 & 1150 \\
\hline \begin{tabular}{c} 
Terragido sediments \\
\hline TEL $^{4}$
\end{tabular} & $18-64$ & $<$ DL & $<$ DL & $32-128$ & $39-93$ & $18-80$ & $49-160$ & $207-334$ & $1705-2681$ \\
\hline PEL $^{4}$ & 17 & 9.9 & - & 37.3 & 35.7 & 18 & 35 & 123 & - \\
\hline
\end{tabular}

${ }^{1}$ Turekian and Wedepohl, in Salomons and Förstner (1984); ${ }^{2}$ Wedepohl, in Salomons and Förstner (1984); ${ }^{3}$ Martin and Meybeck, in Salomons and Förstner (1984); ${ }^{4}$ TEL—-threshold effect level; LEL—lowest effect level; PEL—probable effect level (USEPA, 2000). 
If we consider the spatial distribution, we observe that the total contents are slightly higher in the upstream zone of the reservoir, at and near the confluence of the tributaries (sampling sites 6, 7, 8 and 9; Figure 2). Peaks of contents for As, $\mathrm{Cr}$ and $\mathrm{Ni}$ are registered near the right margin of the reservoir (sampling site 6), where the depth of water is higher, while $\mathrm{Cu}$ and $\mathrm{Zn}$ are higher near the left margin (sampling site 7). Lead shows higher contents at sampling site 2. At the River Corgo, near the entrance of the reservoir, an increase in contents of $\mathrm{Pb}, \mathrm{Ni}, \mathrm{Cu}, \mathrm{As}$ and $\mathrm{Cr}$ (sampling site 8) is observed. The distribution of the metals in the reservoir is uneven, and no clear distribution trend can be observed.

\subsubsection{Evaluation of the Potential Availability of As and Metals}

Considering the assumed relation between potential bioavailability and mobility [1,2], the studied elements could be classed, in general, by their potential relative mobility as follows: $\mathrm{Zn}>\mathrm{As}, \mathrm{Pb}>\mathrm{Cu}>\mathrm{Cr}$, Ni. All the studied geochemical phases play an important role in the retention/transport of the elements; among the most labile fractions, the reducible fraction was the most significant (Table 3; Figure 2).

The results showed that $\mathrm{Zn}$ is retained in significant proportions in the available phase (18-40\%), while As (3-13\%), Ni (3-12\%), Pb (3-8\%) and $\mathrm{Cu}(1-7 \%)$ also occur as exchangeable metals in the sediments. This fraction is the most labile and corresponds to the metal contents that are weakly bound to the sediment particles and is therefore a marker of the pollution potential of the metals linked with the sediments. Several authors attribute the most recent contamination to this phase-e.g., $[1,2,7,46]$. Relatively higher contents of $\mathrm{Zn}$, in the available fraction, are observed in samples collected in the tributaries, near the entrance of the reservoir (sampling sites 7, 8 and 9).

The reducible phase (Fe and Mn hydroxides) preferentially incorporates $\mathrm{Pb}(42-60 \%)$, followed by As (32-91\%) and $\mathrm{Zn}(19-26 \%)$ and lower amounts of $\mathrm{Cu}(8-21 \%)$ and $\mathrm{Ni}$ $(4-11 \%)$. The higher metal contents in this phase generally occur at the sampling sites of the reservoir where the total contents are also higher. The oxides of $\mathrm{Fe}$ and $\mathrm{Mn}$ are sensitive to the physicochemical parameters of the fluvial water: Under reducing conditions and a medium to acid $\mathrm{pH}$, the oxides/hydroxides of $\mathrm{Fe}$ and $\mathrm{Mn}$ are solubilized; high concentrations of organic matter also lead to the reduction or the formation of coatings on the surfaces of the oxides/hydroxides of Fe and Mn [1,7].

The oxidizable phase (organic phase) is important in the retention of $\mathrm{Cu}(26-47 \%), \mathrm{Cr}$ (12-28\%), $\mathrm{Ni}(8-18 \%), \mathrm{Zn}(9-15 \%)$ and $\mathrm{Pb}(8-15 \%)$. Arsenic (0 to 7\%) was detected in two sampling sites and occurred in minor proportions in this geochemical phase. The higher $\mathrm{Cu}$ contents in this phase occurred in samples 7,8 and 9, collected in the more upstream zone of the reservoir and in the tributaries. Apparently, $\mathrm{Cu}$ shows greater affinity for organics when the organic content increases in river water and sediments, forming organic complexes with $\mathrm{Cu}$. In oxic sediments from the drainage area upstream of the Terragido dam [39], $\mathrm{Cu}$ appears correlated to urban effluent discharges. In fact, higher proportions of $\mathrm{Cu}$ in the oxidizable phase were detected in samples collected in the vicinity of urban settlements, whereas in stream reaches with no influence of sewage inputs, a preferential association to reducible phase was observed. A similar observation was reported by [34] for the Lot-Garonne fluvial system. The Terragido reservoir is located downstream of a major urban area surrounded by urban settlements, which might lead to an accumulation of organic compounds in the bottom sediments.

The residual phase contains relevant proportions of $\mathrm{Cr}(63-84 \%)$ and $\mathrm{Ni}(65-84 \%)$, which are concentrated almost entirely in this phase. Hence, these metals are less available for the reservoir water. The other elements studied are also present in significant quantities: $\mathrm{Cu}(35-64 \%), \mathrm{As}(25-58 \%), \mathrm{Zn}(25-50 \%)$ and $\mathrm{Pb}(26-42 \%)$. This would indicate a significant contribution of natural origin, derived from the source rocks outcropping in the drained area. 

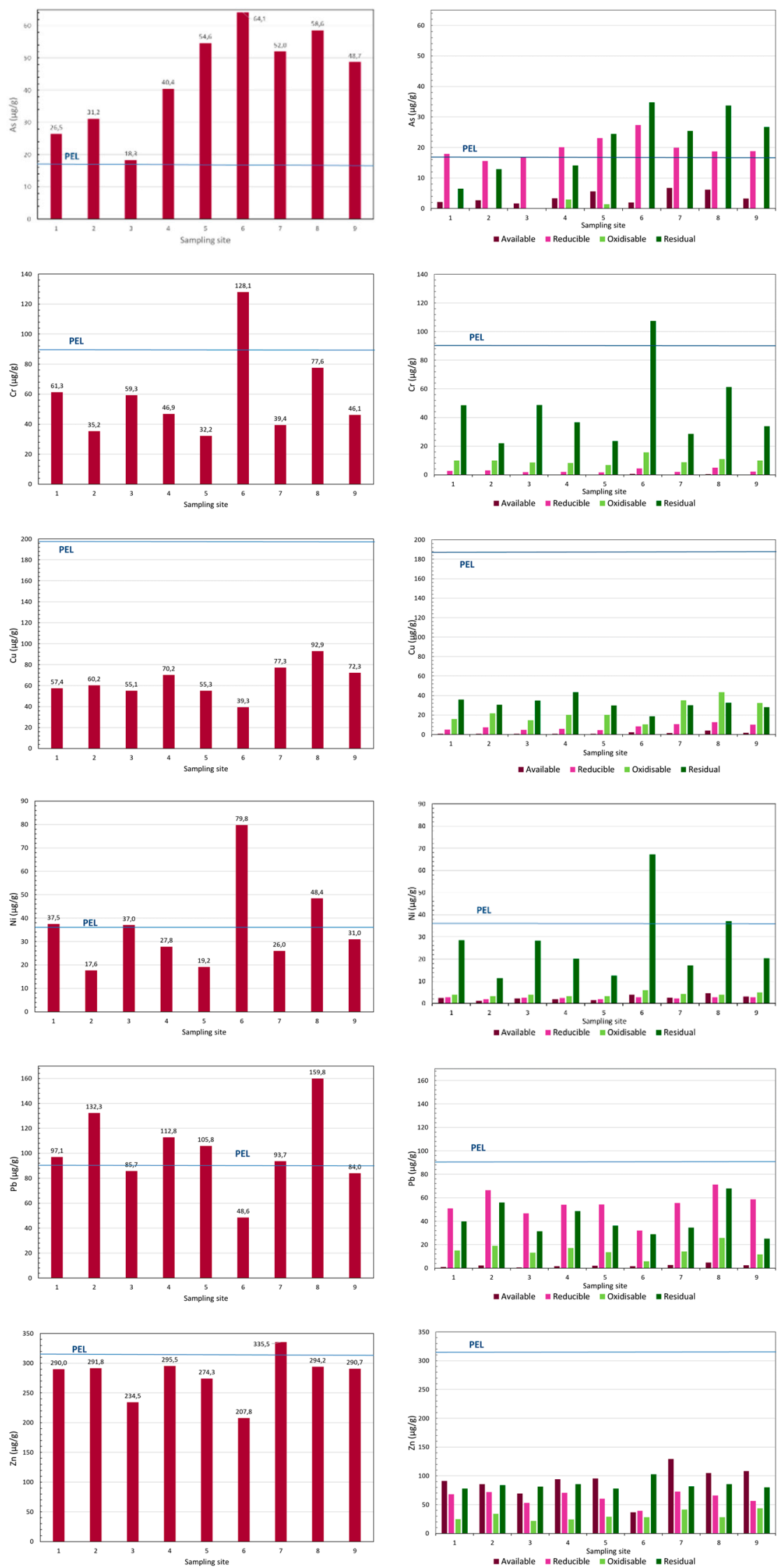

Figure 2. Distribution of $\mathrm{As}, \mathrm{Cr}, \mathrm{Ni}, \mathrm{Pb}$ and $\mathrm{Zn}$ contents as totals and distributed among the geochemical phases in the bottom sediments (fraction $<63 \mu \mathrm{m}$ ) of the Terragido reservoir. The PEL values are marked. Geochemical phases: $\square$ available; $\square$ reducible; $\square$ oxidizable; $\square$ residual. 
Table 3. Means of As and metal contents $\left(\mu \mathrm{g} \mathrm{g}^{-1}\right)$ for each sampling site, extracted from each step of sequential extraction of the bottom sediments from the Terragido reservoir (fraction $\leq 63 \mu \mathrm{m})$ (DL.: detection limit).

\begin{tabular}{|c|c|c|c|c|c|c|c|c|c|c|}
\hline & \multirow{2}{*}{ Fraction } & \multicolumn{9}{|c|}{ Sampling Site } \\
\hline & & 1 & 2 & 3 & 4 & 5 & 6 & 7 & 8 & 9 \\
\hline \multirow[t]{4}{*}{ As } & Available & 2.11 & 2.73 & 1.63 & 3.33 & 5.61 & 1.98 & 6.74 & 6.16 & 3.23 \\
\hline & Reducible & 17.86 & 15.53 & 16.71 & 20.09 & 23.09 & 27.32 & 19.88 & 18.68 & 18.78 \\
\hline & Oxidizable & $<\mathrm{DL}$ & $<\mathrm{DL}$ & $<\mathrm{DL}$ & 2.92 & 1.39 & $<\mathrm{DL}$ & $<\mathrm{DL}$ & $<\mathrm{DL}$ & $<$ DL \\
\hline & Residual & 6.50 & 12.89 & $<\mathrm{DL}$ & 14.09 & 24.47 & 34.79 & 25.38 & 33.75 & 26.69 \\
\hline \multirow[t]{4}{*}{$\mathrm{Cr}$} & Available & 0.13 & 0.10 & 0.09 & 0.04 & 0.10 & 0.69 & 0.08 & 0.53 & 0.08 \\
\hline & Reducible & 2.74 & 3.10 & 1.91 & 2.01 & 1.64 & 4.41 & 1.99 & 4.90 & 2.12 \\
\hline & Oxidizable & 9.89 & 9.95 & 8.62 & 8.16 & 6.90 & 15.55 & 8.73 & 10.90 & 10.02 \\
\hline & Residual & 48.53 & 22.08 & 48.65 & 36.66 & 23.58 & 107.39 & 28.54 & 61.24 & 33.91 \\
\hline \multirow[t]{4}{*}{$\mathrm{Cu}$} & Available & 0.75 & 0.79 & 0.69 & 0.82 & 0.71 & 2.13 & 1.56 & 4.06 & 1.78 \\
\hline & Reducible & 5.07 & 7.19 & 4.85 & 5.79 & 4.49 & 8.27 & 10.56 & 12.72 & 10.21 \\
\hline & Oxidizable & 15.83 & 21.78 & 14.56 & 20.21 & 20.18 & 10.23 & 35.13 & 43.55 & 32.21 \\
\hline & Residual & 35.76 & 30.43 & 34.96 & 43.32 & 29.86 & 18.66 & 30.00 & 32.55 & 28.07 \\
\hline \multirow[t]{4}{*}{$\mathrm{Ni}$} & Available & 2.40 & 1.11 & 2.19 & 1.98 & 1.36 & 3.83 & 2.55 & 4.60 & 3.04 \\
\hline & Reducible & 2.69 & 1.99 & 2.64 & 2.40 & 1.91 & 2.76 & 2.16 & 2.77 & 2.75 \\
\hline & Oxidizable & 3.94 & 3.13 & 3.86 & 3.27 & 3.29 & 6.01 & 4.23 & 3.89 & 4.86 \\
\hline & Residual & 28.45 & 11.37 & 28.30 & 20.17 & 12.56 & 67.18 & 17.08 & 37.12 & 20.31 \\
\hline \multirow[t]{4}{*}{$\mathrm{Pb}$} & Available & 1.05 & 2.33 & 0.66 & 1.55 & 1.98 & 1.64 & 2.66 & 4.67 & 2.51 \\
\hline & Reducible & 50.94 & 66.42 & 46.73 & 54.00 & 54.23 & 32.02 & 55.55 & 71.25 & 58.58 \\
\hline & Oxidizable & 15.09 & 19.02 & 13.19 & 17.05 & 13.47 & 5.72 & 14.25 & 25.81 & 11.58 \\
\hline & Residual & 39.80 & 55.98 & 31.45 & 48.68 & 36.32 & 28.85 & 34.58 & 67.89 & 25.00 \\
\hline \multirow[t]{4}{*}{$\mathrm{Zn}$} & Available & 91.06 & 85.74 & 69.15 & 94.26 & 95.44 & 36.59 & 129.21 & 105.01 & 108.14 \\
\hline & Reducible & 68.16 & 71.81 & 52.86 & 70.79 & 60.49 & 39.15 & 72.75 & 65.72 & 56.41 \\
\hline & Oxidizable & 24.97 & 34.04 & 21.64 & 24.38 & 29.02 & 28.13 & 41.60 & 28.19 & 43.79 \\
\hline & Residual & 77.99 & 83.77 & 81.20 & 85.46 & 78.11 & 102.97 & 81.55 & 85.65 & 79.90 \\
\hline
\end{tabular}

The affinity of a specific metal for a specific geochemical phase has been outlined by several authors-e.g., $[1,2,54]$. Copper shows a tendency to associate with the organic phase. The great stability of the $\mathrm{Cu}$ organic complexes has been outlined by Stumm and Morgan [45]. Under oxidizing conditions, the degradation of organic matter can lead to the mobilization of $\mathrm{Cu}$. The reducible phase is usually an important sink for metals. The hydroxides of Fe and Mn are important as scavengers of all studied metals, as outlined in the literature $[55,56]$, followed by organics. A similar preferred association of $\mathrm{Pb}$ and $\mathrm{Cu}$ to the reducible and oxidizable phases, respectively, was identified in reservoir sediments of South Portugal $[57,58]$.

The partition of element through the geochemical phases, and the balance between contents associated with the most mobile fractions and with the residual fraction, suggest an important contribution from lithology to the total contents of $\mathrm{Cr}$ and $\mathrm{Ni}$, and of anthropogenic activities to those of $\mathrm{Cu}, \mathrm{Pb}$ and $\mathrm{Zn}$ in the sediments from the Terragido reservoir. Arsenic probably has a mixed origin: a natural one, related to the weathering of schists and local quartz veins with sulfides, occurring in the draining area upstream of the dam, and from fertilizers, in particular NPK fertilizer, as As is frequently used in this product $[59,60]$.

\subsubsection{Pattern of Distribution of Metals in the Bottom Sediments of the Reservoir}

The distribution of metal content along the reservoir was uneven; nevertheless, the sampling sites located in the upstream part of the reservoir showed anomalously higher values (sampling site 6-As, $\mathrm{Cr}$, Ni; sampling site $7-\mathrm{Zn}$; sampling site 8 - Pb). The pattern of distribution of contents amid the studied geochemical phases accompanies this trend. In the sediment samples where the total contents are high, the partial contents associated with the sediment phases also showed a relative increase. Near the dam (sampling sites 1 and 2), the $\mathrm{Cu}$ contents in the reducible and oxidizable fraction showed a slight increase. At these 
sampling sites, the values of conductivity and total suspended solids were also higher, while the dissolved oxygen was lower. In sample 6, Cr and Ni show considerably higher contents related to the residual fraction. The observed spatial trend is in agreement with the sedimentation model usually described for dam reservoirs located in mountainous regions. In this type of reservoir, there is an accumulation of sediments in the upstream zone that form a bank due to the speed of water when it encounters the stagnant water body; downstream of the reservoir, the bottom profile becomes relatively sharper, with a relatively lower deposition rate. However, further studies are needed on some parameters of sediments, such as particle size, and their spatial distribution to help to more precisely understand the settlement areas and the evolution of the sediment from the upstream to the downstream zones in the dam.

\subsubsection{Contamination and Risk Assessment of Sediments by As and Metals}

To quantify the degree of depletion/enrichment of the studied elements relative to the geological background, due to anthropogenic activities and/or weathering, the EF values were determined. The results indicate a significant enrichment of $\mathrm{As}, \mathrm{Pb}$ and $\mathrm{Zn}$. Near the dam, As showed a strong enrichment. Conversely, $\mathrm{Cr}, \mathrm{Cu}$ and Ni showed local deficiency, due probably to hydrodynamic sorting.

Taking into account the percentages of As and metals in the most labile fraction, the RAC results (Figure 3 ) show that As, in sediment from sampling sites 7 and 8, may represent a medium risk, as well as $\mathrm{Ni}$ at sampling site 3 . Zinc, according to RAC, represents a high ecologic risk. However, based on the classification of the SQGs, established to predict the toxicity of freshwater sediments, all the studied elements in the sediments showed values above TEL (Table 2 and Figure 2), and this could cause adverse effects on aquatic ecosystems. The maximum values of contents for $\mathrm{As}, \mathrm{Cr}, \mathrm{Ni}, \mathrm{Pb}$ and $\mathrm{Zn}$ were above PEL, indicating that these were associated with frequently adverse effects: As overall in the reservoir; $\mathrm{Pb}$ at almost all sampling sites except 3, 6 and 9; $\mathrm{Ni}$ at sampling sites 1, 3, 6 and 8; $\mathrm{Cr}$ at sampling site 6; and $\mathrm{Zn}$ at sampling site 7 .

\begin{tabular}{|c|c|c|c|c|c|c|}
\hline Site & As & $\mathrm{Cr}$ & $\mathrm{Cu}$ & $\mathrm{Ni}$ & $\mathrm{Pb}$ & $\mathrm{Zn}$ \\
\hline 1 & 12 & 2 & 2 & 2 & 10 & 7 \\
\hline 2 & 16 & 2 & 3 & 1 & 16 & 8 \\
\hline 3 & 9 & 2 & 2 & 3 & 9 & 6 \\
\hline 4 & 19 & 2 & 3 & 2 & 12 & 8 \\
\hline 5 & 26 & 1 & 2 & 1 & 11 & 7 \\
\hline 6 & 24 & 4 & 1 & 4 & 4 & 4 \\
\hline 7 & 23 & 1 & 3 & 2 & 10 & 8 \\
\hline 8 & 26 & 3 & 4 & 3 & 16 & 7 \\
\hline 9 & 21 & 2 & 3 & 2 & 9 & 7 \\
\hline $\mathrm{EF} \leq 2$ & \multicolumn{6}{|c|}{ Deficiency to minimal enrichment } \\
\hline $2<\mathrm{EF} \leq 5$ & \multicolumn{6}{|c|}{ Moderate enrichment } \\
\hline $2<\mathrm{EF} \leq 20$ & \multicolumn{6}{|c|}{ Significant enrichment } \\
\hline $20<\mathrm{EF} \leq 40$ & \multicolumn{6}{|c|}{ Very high enrichment } \\
\hline
\end{tabular}

\begin{tabular}{|c|c|c|c|c|c|c|}
\hline Site & As & $\mathrm{Cr}$ & $\mathrm{Cu}$ & $\mathrm{Ni}$ & $\mathrm{Pb}$ & $\mathrm{Zn}$ \\
\hline 1 & $8,0 \%$ & $0,5 \%$ & $2,9 \%$ & $9,1 \%$ & $4,0 \%$ & $34,7 \%$ \\
\hline 2 & $8,8 \%$ & $0,3 \%$ & $2,6 \%$ & $3,6 \%$ & $7,5 \%$ & $31,1 \%$ \\
\hline 3 & $8,9 \%$ & $0,5 \%$ & $3,8 \%$ & $12,0 \%$ & $3,6 \%$ & $30,8 \%$ \\
\hline 4 & $8,2 \%$ & $0,1 \%$ & $2,0 \%$ & $4,9 \%$ & $3,8 \%$ & $34,3 \%$ \\
\hline 5 & $10,3 \%$ & $0,2 \%$ & $1,3 \%$ & $2,5 \%$ & $3,6 \%$ & $36,3 \%$ \\
\hline 6 & $3,1 \%$ & $1,1 \%$ & $3,3 \%$ & $6,0 \%$ & $2,6 \%$ & $17,7 \%$ \\
\hline 7 & $13,0 \%$ & $0,2 \%$ & $3,0 \%$ & $4,9 \%$ & $5,1 \%$ & $39,7 \%$ \\
\hline 8 & $10,5 \%$ & $0,9 \%$ & $6,9 \%$ & $7,9 \%$ & $8,0 \%$ & $36,9 \%$ \\
\hline 9 & $6,6 \%$ & $0,2 \%$ & $3,7 \%$ & $6,2 \%$ & $5,2 \%$ & $37,5 \%$ \\
\hline RAC $\leq 1 \%$ & \multicolumn{6}{|c|}{ sediment is of no risk to the aquatic environment } \\
\hline $1 \%<\operatorname{RAC} \leq 10 \%$ & \multicolumn{6}{|l|}{ low risk } \\
\hline $11 \%<R A C \leq 30 \%$ & \multicolumn{6}{|c|}{ medium risk } \\
\hline $31 \%<R A C \leq 50 \%$ & \multicolumn{6}{|l|}{ high risk } \\
\hline RAC $>50 \%$ & \multicolumn{6}{|c|}{$\begin{array}{l}\text { sediment poses a very high risk } \\
\text { it is considered very dangerous }\end{array}$} \\
\hline
\end{tabular}

Figure 3. Enrichment factors (EF) of metals and risk assessment code (RAC) of bottom sediments from the Terragido reservoir.

\subsubsection{Evaluation of the Potential Availability of $P$}

The total amount of $\mathrm{P}$ obtained from the sum of the different $\mathrm{P}$ fractions varied between $1705 \mu \mathrm{g} \mathrm{g}^{-1}$ and $2681 \mu \mathrm{g} \mathrm{g}^{-1}$ (Figure 4). When considering the sum of the most reactive $\mathrm{P}$ fractions $\left(\mathrm{NH}_{4} \mathrm{Cl}-\mathrm{P}, \mathrm{Al}-\mathrm{P}, \mathrm{Fe}-\mathrm{P}, \mathrm{CDB}-\mathrm{P}\right.$ and $\left.\mathrm{Ca}-\mathrm{P}\right)$, the highest amounts of total $\mathrm{P}$ were observed at sampling sites 8 and 2 (2454 and $2081 \mu \mathrm{g} \mathrm{g}^{-1}$, respectively), located at the River Corgo, near the entrance of the reservoir and near the wall of the dam, respectively. The lowest contents are observed at sampling site $3\left(1484 \mathrm{\mu g} \mathrm{g}^{-1}\right)$ in the central zone of the reservoir downstream near the left margin, and at site $7\left(1518 \mu \mathrm{g} \mathrm{g}^{-1}\right)$, where the two tributaries join at the entrance of the reservoir. While the total $\mathrm{P}$ content may be of concern, $\mathrm{P}$ fractionation plays an important role in determining the impact of this element on the system as some fractions are available for biotic uptake, while others sequester 
it as relatively immobile phases. In terms of percentage distribution, results show the predominance of Fe-P (34-48\%), followed by Al-P (21-48\%), then Ca-P (13-24\%), CDB-P $(5-13 \%)$ and $\mathrm{NH}_{4} \mathrm{Cl}-\mathrm{P}$, which was $<0.1 \%$ in all the samples.
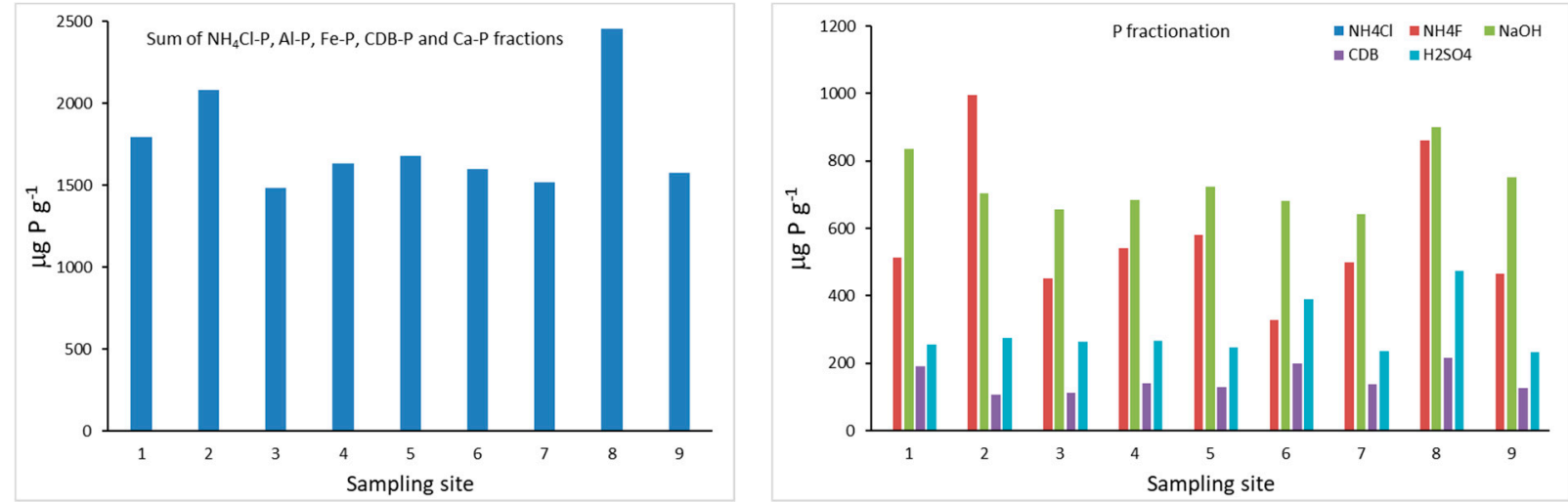

Figure 4. Chang and Jackson $\mathrm{P}$ fractions $\left(\mathrm{mg} \mathrm{P} \mathrm{kg}^{-1}\right)$ obtained for the bottom sediments of the Terragido reservoir. Phosphorus fractions: $\mathrm{NH}_{4} \mathrm{Cl} ; \mathbf{\mathrm { NH }} \mathrm{F}$; $\mathrm{NaOH} ; \mathrm{CDB} ; \mathrm{H}_{2} \mathrm{SO}_{4}$.

When considering the individual fractions (Table 4), we observe that $\mathrm{NH}_{4} \mathrm{Cl}-\mathrm{P}$, loosely bound $\mathrm{P}$ that can be easily released to the overlying water [61] or leached from decaying cells of bacterial biomass in deposited phytodetrital aggregates [62], has not exceeded the value of $1.23 \mathrm{\mu g} \mathrm{g}^{-1}$ (site 9 , one of the tributaries). The lowest values were observed at sites $1\left(0.20 \mu \mathrm{g} \mathrm{g}^{-1}\right)$ and $6\left(0.18 \mu \mathrm{g} \mathrm{g}^{-1}\right)$. The very low $\mathrm{NH}_{4} \mathrm{Cl}-\mathrm{P}$ concentrations observed in the current study, and the small variations registered between the different sampling sites, may be related to the reservoir characteristics (high hydrodynamics). The $\mathrm{NH}_{4} \mathrm{Cl}-\mathrm{P}$ concentrations may present seasonal variations related to land use patterns as well as metal concentrations ( $\mathrm{Fe}, \mathrm{Al}$ and $\mathrm{Ca}$ ). In the present work, the data refer to a single sampling date which took place during the end of the dry season, and [63] registered higher amounts of $\mathrm{NH}_{4} \mathrm{Cl}-\mathrm{P}$ in sediments from South Han River, South Korea, at the end of the dry season.

Table 4. Data of content of different $\mathrm{P}$ fractions $\left(\mu \mathrm{g} \mathrm{g}^{-1}\right)$ of sediments in the Terragido reservoir.

\begin{tabular}{|c|c|c|c|c|c|}
\hline Sampling Site & $\begin{array}{c}\text { ES-P }\left(\mu \mathrm{g} \mathrm{g}^{-1}\right) \\
1 \mathrm{M} \mathrm{NH}{ }_{4} \mathrm{CI}\end{array}$ & $\begin{array}{c}\mathrm{Al}-\mathrm{P}\left(\mu \mathrm{g} \mathrm{g}^{-1}\right) \\
0.5 \mathrm{M} \mathrm{NH}_{4} \mathrm{~F}\end{array}$ & $\begin{array}{c}\mathrm{Fe}-\mathrm{P}\left(\mu \mathrm{g} \mathrm{g}^{-1}\right) \\
0.1 \mathrm{M} \mathrm{NaOH}\end{array}$ & $\begin{array}{c}\text { RS-P }\left(\mu g^{-1}\right) \\
\text { CDB }\end{array}$ & $\begin{array}{l}\mathrm{Ca}-\mathrm{P}\left(\mu \mathrm{g} \mathrm{g}^{-1}\right) \\
0.25 \mathrm{M} \mathrm{H}_{2} \mathrm{SO}_{4}\end{array}$ \\
\hline 1 & 0.20 & 513.90 & 834.31 & 190.98 & 254.72 \\
\hline 2 & 0.86 & 994.73 & 704.32 & 107.40 & 273.87 \\
\hline 3 & 0.53 & 451.62 & 655.66 & 113.60 & 262.59 \\
\hline 4 & 1.04 & 542.36 & 684.34 & 140.53 & 267.73 \\
\hline 5 & 0.56 & 580.03 & 723.41 & 128.69 & 246.31 \\
\hline 6 & 0.18 & 328.09 & 681.40 & 200.04 & 389.15 \\
\hline 7 & 0.61 & 498.33 & 643.23 & 138.68 & 236.92 \\
\hline 8 & 0.98 & 861.65 & 900.21 & 216.97 & 474.49 \\
\hline 9 & 1.23 & 465.10 & 751.24 & 126.04 & 234.30 \\
\hline
\end{tabular}

The Al-P fraction revealed the highest concentrations at sampling sites $2\left(995 \mu \mathrm{g} \mathrm{g}^{-1}\right)$ and $8\left(862 \mu \mathrm{g} \mathrm{g}^{-1}\right)$, while the lowest amount was observed at sampling site $6\left(328 \mu \mathrm{g} \mathrm{g}^{-1}\right)$. Al-P is associated with aluminosilicate clay minerals or as discrete aluminum phosphate phases. Fe-P fraction showed a smaller range of variation when compared to Al-P. The highest concentrations are observed at sampling sites $8\left(900 \mu \mathrm{g} \mathrm{g}^{-1}\right)$ and $1\left(834 \mu \mathrm{g} \mathrm{g}^{-1}\right)$, and the lowest was observed at site $7\left(643 \mu \mathrm{g} \mathrm{g}^{-1}\right)$. Aluminum and Al hydroxide are considered a permanent sink for $\mathrm{P}$ in the water column and sediment, as they form strong bonds with phosphate and are unaffected by redox conditions; conversely, P bound to Fe can be released into the water column by altering $\mathrm{pH}$ and redox potential [63].

CDB-P concentrations are low in all the samples when compared to the amounts of $\mathrm{P}$ extracted by the Al-P and Fe-P fractions, and the highest concentration is also observed at 
sampling site $8\left(217 \mu \mathrm{g} \mathrm{g}^{-1}\right)$. The CDB fraction includes Fe and $\mathrm{Al}$ phosphates, protected by an inert coat preventing their reaction in soil solution, and reductant soluble forms, which may be partially or totally dissolved under anaerobic conditions [64].

Calcium bound $\mathrm{P}$ is also considered permanently bound [65] and presented concentrations varying between $107 \mu \mathrm{g} \mathrm{g}^{-1}$ at sampling site 2 and $217 \mu \mathrm{g} \mathrm{g}^{-1}$ at sampling site 8. Within the Ca-P fraction, concentrations observed at sampling sites 6 and 8 reached the highest values-389 and $474 \mu^{-1} \mathrm{~g} \mathrm{~g}^{-1}$, respectively. The other sampling sites registered similar values, averaging $254 \mu \mathrm{g} \mathrm{g}^{-1}$.

Overall, the results from the Chang and Jackson $P$ fractionation reveal that sediments sampled at sites 8 and 2 presented higher total $P$ concentrations. However, sediments from site 8 may present a higher risk of contributing to water $\mathrm{P}$ enrichment: when the Fe-P and CDB-P fractions reach the highest concentrations and oxygen depletion is higher, they can release $\mathrm{P}$ into the water column.

\section{Conclusions}

The analysis of the reservoir water, both at the surface and near the bottom, does not reveal significant indicators of contamination, showing little variation in the chemical parameters. The chemical signature reflects the composition of the drained lithologies and the fluvial dynamics in mountainous catchments.

All the geochemical phases studied are important in the retention of As and metals. Within the most labile fractions, the reducible fraction is the most significant. The relative mobility of the studied elements is as follows: $\mathrm{Zn}>\mathrm{As}, \mathrm{Pb}>\mathrm{Cu}>\mathrm{Cr}$, Ni. Significant contents of $\mathrm{Zn}$ are associated with the most labile fraction; the organic phase is important in the retention of $\mathrm{Cu}$. The larger proportions of $\mathrm{Cr}$ and $\mathrm{Ni}$ are associated with the residual phase, and therefore, these metals are less available to the river water. The distribution pattern of metals among the geochemical phases is related to the type of contamination sources and lithology occurring in the drained area.

The analysis of the geochemical partition of metals has proved very important for the evaluation of environmental quality. The joint analysis of fractionation, EF, RAC and SQGs allowed establishing the level of enrichment of the studied elements and identifying which elements could pose a risk to the reservoir ecosystem. Arsenic, $\mathrm{Cr}, \mathrm{Ni}, \mathrm{Pb}$ and $\mathrm{Zn}$ show total contents exceeding the values of PEL, but only As occurs in the largest number of potentially available forms; $\mathrm{Cr}$ and $\mathrm{Ni}$, although showing higher values than the reference ones, can be considered relatively unavailable since they are essentially associated with the residual phase.

Regarding the most reactive $\mathrm{P}$ fractions $\left(\mathrm{NH}_{4} \mathrm{Cl}-\mathrm{P}, \mathrm{Al}-\mathrm{P}, \mathrm{Fe}-\mathrm{P}, \mathrm{CDB}-\mathrm{P}\right.$ and $\left.\mathrm{Ca}-\mathrm{P}\right)$, these were high at a few sampling sites, and $\mathrm{P}$ fractionation revealed that local sediments may present a higher risk of contributing to water $\mathrm{P}$ enrichment, in particular where fractions Fe-P and CDB-P reached higher concentrations and oxygen depletion was higher.

This study showed that the total potentially available and/or total amounts of As, metals and $\mathrm{P}$ present in the reservoir sediments are relatively high when compared to those mentioned in the references. This indicates that the quality of bottom sediments accumulated in small reservoirs should be considered in management policies, in particular the management of reservoir dredge sediments, following this sequence: mountainous areasdelivery of coarse sediments which trap finer sediments in spaces between particlessmall reservoir capacity - maintenance with dredging of bottom sediments-deposition of dredge sediments. Small reservoirs, although possessing less sediment retention capacity, are widely distributed in regulated basins and as a result collectively confer an important anthropogenic signature to the global sedimentary flow. This study also confirms the need to further investigate the presence of $\mathrm{P}$ in mountainous catchments, even in reservoirs of the "riverine reservoir" type. 
Author Contributions: Conceptualization, A.R.R. and M.R.; methodology, A.R.R. and M.R.; formal analysis, S.G.P.V., J.P.R.M.P. and B.V.; investigation, A.R.R. and M.R.; data curation, L.F.S.F.; writingoriginal draft preparation, A.R.R. and M.R.; writing—review and editing, F.A.L.P.; supervision, A.R.R. and M.R. All authors have read and agreed to the published version of the manuscript.

Funding: This research was developed in the ambit of INTERACT project-“'Integrated Research in Environment, Agro-Chain and Technology", no. NORTE-01-0145-FEDER-000017, in its line of research entitled BEST_- "Bioeconomy and Sustainability”, co-financed by the European Regional Development Fund (ERDF) through NORTE 2020 (North Regional Operational Program 2014/2020) and by Portuguese funds by Fundação para a Ciência e Tecnologia, I.P. (Portugal) in the frame of the UIDB/00073/2020 and UIDP/00073/2020 projects of the I\&D unit Geosciences Center (CGEO). For authors integrated in the CITAB research center, this work was supported by National Funds by FCT-Portuguese Foundation for Science and Technology, under the project UIDB/04033/2020. The authors integrated in the CITAB research center are also integrated in the Inov4Agro-Institute for Innovation, Capacity Building and Sustainability of Agri-food Production. The Inov4Agro is an Associate Laboratory composed of two R\&D units (CITAB and GreenUPorto). For the authors integrated in the CQVR, the research was additionally supported by National Funds by FCTPortuguese Foundation for Science and Technology, under the project UIDB/QUI/00616/2020 and UIDP/00616/2020.

Institutional Review Board Statement: Not applicable.

Informed Consent Statement: Not applicable.

Data Availability Statement: The study does not report any data.

Acknowledgments: The authors are grateful to Anne Dudley and Martin Heaps for assistance in the analytical work related to the sediment samples performed in the Department of Geography and Environmental Science of the University of Reading, UK, and to Carlos Matos for the assistance in the analytical work related to water samples, performed in the Chemistry Department of the University of Trás-os-Montes e Alto Douro.

Conflicts of Interest: The authors declare no conflict of interest. The funders had no role in the design of the study; in the collection, analyses, or interpretation of data; in the writing of the manuscript, or in the decision to publish the results.

\section{References}

1. Förstner, U.; Wittmann, G.T.W. Metal Pollution in the Aquatic Environment; Springer: Berlin, Germany, 1979.

2. Salomons, W.; Förstner, U. Metals in the Hydrocycle; Springer: New York, NY, USA, 1984.

3. Salomons, W.; Rooij, N.M.; Kerdijk, H.; Bril, J. Sediments as a source for contaminants? Hydrobiologia 1987, 149, 13-30. [CrossRef]

4. Salomons, W. Sediment Pollution in the EEC; Office for Official Publications of the European Communities: Luxembourg, 1993.

5. Salomons, W.; Stigliani, W.M. Biogeodynamics of Pollutants in Soils and Sediments: Risk Assessment of Delayed and Non-Linear Responses; Springer: Berlin, Germany; London, UK, 1995.

6. Calmano, W.; Förstner, U. Sediments and Toxic Substances: Environmental Effects and Ecotoxity; Springer: Berlin, Germany, 1996.

7. Horowitz, A.J.; Elrick, K.A.; Smith, J.J. Estimating suspended sediment and trace element fluxes in large river basins: Methodological considerations as applied to the NASQAN programme. Hydrol. Process. 2001, 15, 1107-1132. [CrossRef]

8. Förstner, U. Sediment dynamics and pollutant mobility in rivers: An interdisciplinary approach. Lakes Reserv. Res. Manag. 2004, 9, 25-40. [CrossRef]

9. Westrich, B.; Förstner, U. Sediment Dynamics and Pollutant Mobility in Rivers: An Interdisciplinary Approach; Springer: Berlin, Germany, 2007.

10. Pickering, W.F. Metal ion speciation-soils and sediments (a review). Ore Geol. Rev. 1986, 1, 83-146. [CrossRef]

11. Mainstone, C.P.; Parr, W. Phosphorus in rivers-Ecology and management. Sci. Total Environ. 2002, 282, 25-47. [CrossRef]

12. Malmqvist, B.; Rundle, S. Threats to the running water ecosystems of the world. Environ. Conserv. 2002, 29, 134-153. [CrossRef]

13. Directive 2000/60/EC of the European Parliament and of the Council of 23 October 2000 Establishing a Framework for Community Action in the Field of Water Policy. Available online: https:/ / www.eea.europa.eu/policy-documents / directive-2000-60-ec-of (accessed on 22 May 2021).

14. Withers, P.J.A.; Lord, E. Agricultural nutrient inputs to rivers and groundwaters in the UK: Policy, environmental management and research needs. Sci. Total Environ. 2002, 282, 9-24. [CrossRef]

15. Neal, C.; Jarvie, H.P.; Williams, R.; Love, A.; Neal, M.; Wickham, H.; Harman, S.; Armstrong, L. Declines in phosphorus concentration in the upper River Thames (UK): Links to sewage effluent cleanup and extended end-member mixing analysis. Sci. Total Environ. 2010, 408, 1315-1330. [CrossRef] 
16. Raike, A.; Pietilainen, O.P.; Rekolainen, S.; Kauppila, P.; Pitkanen, H.; Niemi, J.; Raateland, A.; Vuorenmaa, J. Trends of phosphorus, nitrogen and chlorophyll a concentrations in Finnish rivers and lakes in 1975-2000. Sci. Total Environ. 2003, 310, 47-59. [CrossRef]

17. Zoboli, O.; Viglione, A.; Rechberger, H.; Zessner, M. Impact of reduced anthropogenic emissions and century flood on the phosphorus stock, concentrations and loads in the Upper Danube. Sci. Total Environ. 2015, 518, 117-129. [CrossRef]

18. Colombo, C.; Barron, V.; Torrent, J. Phosphate adsorption and desorption in relation to morphology and crystal properties of synthetic hematites. Geochim. Cosmochim. Acta 1994, 58, 1261-1269. [CrossRef]

19. Goldberg, S.; Sposito, G. On the mechanism of specific phosphate adsorption by hydroxylated mineral surfaces: A review. Commun. Soil Sci. Plant Anal. 1985, 16, 801-821. [CrossRef]

20. Parfitt, R.L.; Atkinson, R.J.; Smart, R.S.C. The mechanism of phosphate fixation by iron oxides. Soil Sci. Soc. Am. J. 1975, 39, 837-841. [CrossRef]

21. Parfitt, R.L.; Russell, J.D. Adsorption on hydrous oxides. IV. Mechanisms of adsorption of various ions on goethite. J. Soil Sci. 1977, 28, 297-305. [CrossRef]

22. Reddy, K.R.; Kadlec, R.H.; Flaig, E.; Gale, P.M. Phosphorus retention in streams and wetlands: A review. Crit. Rev. Environ. Sci. Technol. 1999, 29, 83-146. [CrossRef]

23. Torrent, J. Interactions between Phosphate and Iron Oxide. Adv. GeoEcol. 1997, 30, 321-344.

24. Gunnars, A.; Blomqvist, S. Phosphate exchange across the sediment-water interface when shifting from anoxic to oxic conditionsan experimental comparison of freshwater and brackish-marine systems. Biogeochemistry 1997, 37, 203-226. [CrossRef]

25. Bartlett, R.J. Characterizing soil redox behavior. In Soil Physical Chemistry, 2nd ed.; Sparks, D.L., Ed.; CRC Press: Boca Raton, FL, USA, 1998.

26. Uusitalo, R.; Turtola, E. Determination of Redox-Sensitive Phosphorus in Field Runoff without Sediment Preconcentration. J. Environ. Qual. 2003, 32, 70-77. [CrossRef]

27. Vörösmarty, C.J.; Meybeck, M.; Fekete, B.; Sharma, K.; Green, P.; Syvitski, J.P.M. Anthropogenic sediment retention: Major global impact from registered river impoundments. Glob. Planet. Chang. 2003, 39, 169-190. [CrossRef]

28. Walling, D.E.; Fang, D. Recent trends in the suspended sediment loads of the world's rivers. Glob. Planet. Chang. 2003, 39, 111-126. [CrossRef]

29. Walling, D.E. Human impact on land-ocean sediment transfer by the world's rivers. Geomorphology 2006, 79, 192-216. [CrossRef]

30. Klaver, G.; van Os, B.; Negrel, P.; Petelet-Giraud, E. Influence of hydropower dams on the composition of the suspended and riverbank sediments in the Danube. Environ. Pollut. 2007, 148, 718-728. [CrossRef] [PubMed]

31. Van Den Berg, G.A.; Loch, J.P.G.; Van Der Heijdt, L.M.; Zwolsman, J.J.G. Mobilisation of heavy metals in contaminated sediments in the river Meuse, The Netherlands. Water Air Soil Pollut. 1999, 166, 567-586. [CrossRef]

32. Simpson, S.L.; Apte, S.C.; Batley, G.E. Effect of short-term resuspension events on the oxidation of cadmium, lead, and zinc sulfide phases in anoxic estuarine sediments. Environ. Sci. Technol. 2000, 34, 4533-4537. [CrossRef]

33. Zoumis, T.; Schmidt, A.; Grigorova, L.; Calmano, W. Contaminants in sediments: Remobilisation and demobilisation. Sci. Total Environ. 2001, 266, 195-202. [CrossRef]

34. Audry, S.; Schäfer, J.; Blanc, G.; Bossy, C.; Lavaux, G. Anthropogenic components of heavy metal (Cd, Zn, Cu, Pb) budgets in the Lot-Garonne fluvial system (France). Appl. Geochem. 2004, 19, 269-286. [CrossRef]

35. Arnason, J.G.; Fletcher, B.A. A 40+ year record of $\mathrm{Cd}, \mathrm{Hg}, \mathrm{Pb}$, and $\mathrm{U}$ deposition in sediments of Patroon Reservoir, Albany County, NY, USA. Environ. Pollut. 2003, 123, 383-391. [CrossRef]

36. Audry, S.; Schäfer, J.; Blanc, G.; Jouanneau, J.M. Fifty-year sedimentary record of heavy metal pollution $(\mathrm{Cd}, \mathrm{Zn}, \mathrm{Cu}, \mathrm{Pb})$ in the Lot River reservoirs (France). Environ. Pollut. 2004, 132, 413-426. [CrossRef]

37. Varol, M.; Gökot, B.; Bekleyen, A.; Şen, B. Spatial and temporal variations in surface water quality of the dam reservoirs in the Tigris River basin, Turkey. Catena 2012, 92, 11-21. [CrossRef]

38. Vukovic, D.; Vukovic, Z.; Stankovic, S. The impact of the Danube Iron Gate Dam on heavy metal storage and sediment flux within the reservoir. Catena 2014, 113, 18-23. [CrossRef]

39. Reis, A.; Parker, A.; Alencoão, A. Storage and origin of metals in active stream sediments from mountainous rivers: A case study in the River Douro basin (North Portugal). Appl. Geochem. 2014, 44, 69-79. [CrossRef]

40. Reis, A.R. Occurrence and Mobilisation of Non-Organic Micro-Pollutants in Mountainous Riverine Systems. Ph.D. Thesis, University of Trás-os-Montes e Alto Douro, Vila Real, Portugal, Unpublished work. 2010; 453p.

41. Matos, A.V. A Geologia da Região de Vila Real. Ph.D. Thesis, University of Trás-os-Montes e Alto Douro, Vila Real, Portugal, Unpublished work. 1991;312p.

42. Neiva, A.M.R.; Gomes, M.E.P. Geochemistry of the granitoid rocks and their minerals from Lixa do Alvão-Alfarela de JalesTourencinho (Vila Pouca de Aguiar, northern Portugal). Chem. Geol. 1991, 89, 305-327. [CrossRef]

43. Förstner, U. Traceability of sediment analysis. Trends Anal. Chem. 2004, 23, 217-236. [CrossRef]

44. Appelo, C.A.J.; Postma, D. Geochemistry, Groundwater and Pollution; A.A. Balkema: Rotterdam, The Netherlands, 1993; 535p.

45. Stumm, W.; Morgan, J.J. Aquatic Chemistry: Chemical Equilibria and Rates in Natural Waters, 3rd ed.; Wiley: New York, NY, USA; Chichester, UK, 1996.

46. Rauret, G.; Lopez-Sanchez, F.J.; Sahuquillo, A.; Rubio, R.; Davidson, C.; Ure, A. Improvement of the BCR three step sequential extraction procedure prior to the certification of new sediment and soil reference materials. J. Environ. Monit. 1999, 1, 57-61. [CrossRef] [PubMed] 
47. Chang, S.C.; Jackson, M.L. Fractionation of soil phosphorus. Soil Sci. 1957, 84, 133-144. [CrossRef]

48. Wang, Y.T.; O'Halloran, I.P.; Zhang, T.Q.; Hu, Q.C.; Tan, C.S. Phosphorus sorption parameters of soil ant their relationships with soil test phosphorus. Soil Sci. Soc. Am. J. 2015, 79, 672-680. [CrossRef]

49. Kuo, S. Phosphorus. In Methods of Soil Analysis Part 3-Chemical Methods; Sparks, D.L., Page, A.L., Helmke, P.A., Loeppert, R.H., Soltanpour, P.N., Tabatabai, M.A., Johnston, T., Sumner, M.E., Eds.; SSSA Book Series 5.3; SSSA, ASA: Madison, WI, USA, 1996; pp. 869-919. [CrossRef]

50. Buat-Menerd, P.; Chesselt, R. Variable influence of the atmospheric flux on the trace metal chemistry of oceanic suspended matter. Earth Planet Sci. Lett. 1979, 42, 398-411. [CrossRef]

51. Grygar, T.M.; Popelka, J. Revisiting geochemical methods of distinguishing natural concentrations and pollution by risk elements in fluvial sediments. J. Geochem. Explor. 2016, 170, 39-57. [CrossRef]

52. Perin, G.; Craboledda, L.; Cirillo, M.; Dotta, L.; Zanette, M.L.; Orio, A.A. Heavy metal speciation in the sediments of Northern Adriatic Sea: A new approach for environmental toxicity determination. In Heavy Metal in the Environment; Lekkas, T.D., Ed.; CEP Consultant: Edinburgh, UK, 1985; Volume 2, pp. 454-456.

53. MacDonald, D.D.; Ingersoll, C.G.; Berger, T.A. Developed and evaluation of consensus-based sediment quality guidelines for freshwater ecosystems. Arch. Environ. Contam. Toxicol. 2000, 39, 20-31. [CrossRef]

54. Baruah, N.K.; Kotoky, P.; Bhattacharyya, K.G.; Borah, G.C. Metal speciation in Jhanji River sediments. Sci. Total Environ. 1996, $193,1-12$. [CrossRef]

55. Macklin, M.G.; Doarsett, R.B. The chemical speciation of trace metals in fine grained overbank flood sediments in the Tyne basin, North East England. Catena 1989, 16, 135-151. [CrossRef]

56. Hudson-Edwards, K.; Macklin, M.G.; Curtis, C.D.; Vaughan, D. Mineralogical forms, processes of formation and distribution of $\mathrm{Pb}, \mathrm{Zn}, \mathrm{Cd}$ and $\mathrm{Cu}$ in the Tyne catchment basin, Northern Pennines, North East England. Environ. Sci. Technol. 1996, 30, 72-80. [CrossRef]

57. Passos, E.D.A.; Alves, J.C.; dos Santos, I.S.; Alves, J.D.P.H.; Garcia, C.A.B.; Spinola Costa, A.C. Assessment of trace metals contamination in estuarine sediments using a sequential extraction technique and principal component analysis. Microchem. J. 2010, 96, 50-57. [CrossRef]

58. Palma, P.; Ledo, L.; Alvarenga, P. Assessment of trace element pollution and its environmental risk to freshwater sediments influenced by anthropogenic contributions: The case study of Alqueva reservoir (Guadiana Basin). Catena 2015, 128, 174-184. [CrossRef]

59. Alloway, B.J.; Ayres, D.C. Chemical Principles of Environmental Pollution, 2nd ed.; Blackie Academic \& Professional: London, UK, 1997; 395p.

60. Terrado, M.; Barceló, D.; Tauler, R. Identification and distribution of contamination sources in the Ebro river basin by chemometrics modelling coupled to geographical information systems. Talanta 2006, 70, 691-704. [CrossRef] [PubMed]

61. Kaiserli, A.; Voutsa, D.; Samara, C. Phosphorus fractionation in lake sediments-Lakes Volvi and Koronia, N. Greece. Chemosphere 2002, 46, 1147-1155. [CrossRef]

62. Pettersson, K. Phosphorus characteristics of settling and suspended particles in Lake Erken. Sci. Total Environ. 2001, 266, 79-86. [CrossRef]

63. Vo, N.X.Q.; Ji, Y.; Doan, T.V.; Kang, H. Distribution of Inorganic Phosphorus Fractions in Sediments of the South Han River over a Rainy Season. Environ. Eng. Res. 2014, 19, 229-240. [CrossRef]

64. Yan, X.; Yang, W.; Chen, X.; Wang, M.; Wang, W.; Ye, D.; Wu, L. Soil Phosphorus Pools, Bioavailability and Environmental Risk in Response to the Phosphorus Supply in the Red Soil of Southern China. Int. J. Environ. Res. Public Health 2020, 17, 7384. [CrossRef]

65. Rydin, E. Potentially mobile phosphorus in lake Erken sediment. Water Res. 2000, 34, 2037-2042. [CrossRef] 